\title{
CORRECTION
}

\section{Correction to: Adverse effect of rheumatoid arthritis on male Wistar rat's fertility: protective role of Costus extract}

\author{
Samar Kamel ${ }^{1} \cdot$ Hend M. Tag ${ }^{2} \cdot$ Hala Ebeid $^{2} \cdot$ Howayda E. Khaled $^{3} \cdot$ Amani A. Almallah $^{4} \cdot$ Mohamed S. El-Naggar $^{2}$ \\ Published online: 11 December 2021 \\ (c) Springer-Verlag GmbH Germany, part of Springer Nature 2021
}

\section{Correction to: Environmental Science and Pollution Research https://doi.org/10.1007/s11356-021-16001-y}

The correct Fig. 1 image is presented in this paper.

Publisher's note Springer Nature remains neutral with regard to jurisdictional claims in published maps and institutional affiliations.

The original article can be found online at https://doi.org/10.1007/

s11356-021-16001-y.

Samar Kamel

samarkame12009@gmail.com

1 Department of Physiology, Faculty of Veterinary Medicine, Suez Canal University, Ismailia, Egypt

2 Zoology Department, Faculty of Sciences, Suez Canal University, Ismailia 41522, Egypt

3 Department of Zoology, Faculty of Sciences, Suez University, Suez, Egypt

4 Department of Anatomy and Embryology, Faculty of Medicine, Suez Canal University, Ismailia, Egypt 


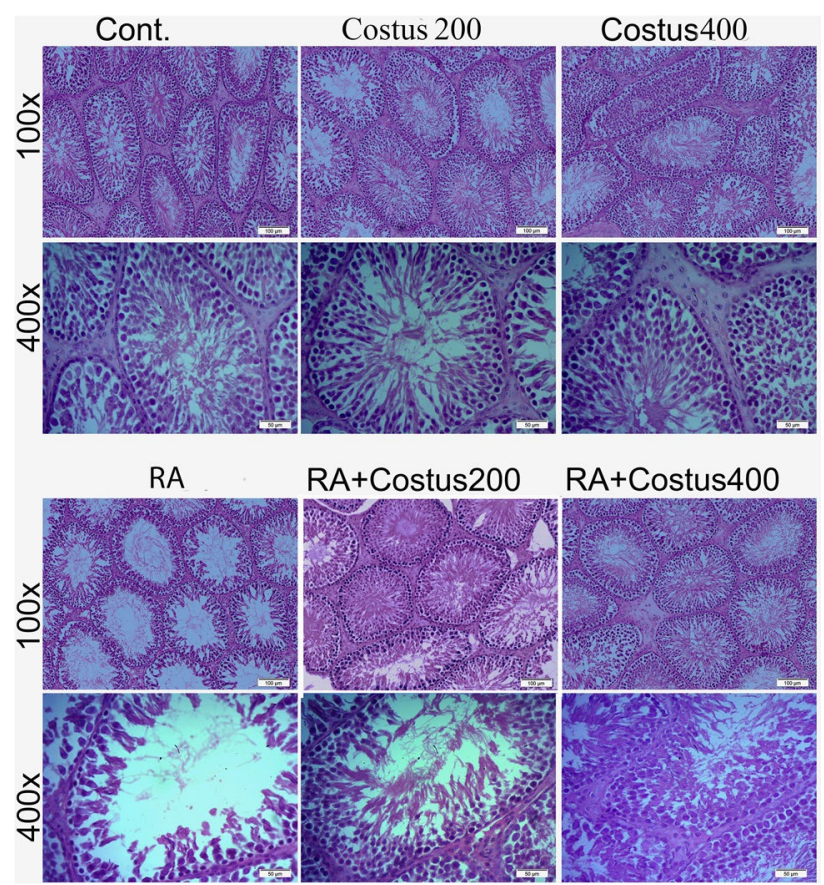

Fig. 1 Control (cont.), Costus (200, $400 \mathrm{mg} / \mathrm{kg}$ ) groups showed normal seminiferous tubules. RA (rheumatic arthritis)-induced group showeddifferent degrees of degeneration in germinal cells with marked depletion of spermatozoa. Treatment with Costus (200, $400 \mathrm{mg} / \mathrm{kg}$ )showed marked improvement (200, $400 \mathrm{mg} / \mathrm{kg}$ ) showed marked improvement. H\&E stain 